medRxiv preprint doi: https://doi.org/10.1101/2022.02.22.22271354; this version posted February 24, 2022. The copyright holder for this preprint (which was not certified by peer review) is the author/funder, who has granted medRxiv a license to display the preprint in It is made available under a CC-BY-NC-ND 4.0 International license .

\title{
MRI connectivity-based spread of microglial activation in early Alzheimer's disease
}

Boris-Stephan Rauchmann, MD, 3,15,16, Matthias Brendel, MD, MHBA ${ }^{2,11}$, Nicolai

Franzmeier, $\mathrm{PhD}^{4}$, Lena Trappmann ${ }^{3}$, Mirlind Zaganjori ${ }^{3}$, Estrella Morenas-Rodriguez, $\mathrm{PhD}^{5,9}$, Selim Guersel, $\mathrm{MD}^{3,5}$, Lena Burow, $\mathrm{MSc}^{3}$, Carolin Kurz, $\mathrm{MD}^{3}$, Jan Haeckert, $\mathrm{MD}^{3,12}$, Maia Tatò $\mathrm{MD}^{3}$, Julia Utecht, $\mathrm{MD}^{3}$, Boris Papazov${ }^{1}$, Oliver Pogarell $\mathrm{MD}^{3}$, Daniel Janowitz, $\mathrm{MD}^{4}$, Katharina Buerger $\mathrm{MD}^{4,5}$, Michael Ewers ${ }^{4}$, Carla Palleis, MD ${ }^{5,6,11}$, Endy Weidinger, MD $^{6}$, Gloria Biechele ${ }^{2}$, Sebastian Schuster ${ }^{2}$, Anika Finze ${ }^{2}$, Florian Eckenweber ${ }^{2}$, Rainer Rupprecht, $\mathrm{MD}^{13}$, Axel Rominger, $\mathrm{MD}^{2,14}$, Oliver Goldhardt, $\mathrm{MD}^{7}$, Timo Grimmer, $\mathrm{MD}$, $\mathrm{PhD}^{7}$, Daniel Keeser, $\mathrm{PhD}^{1,3,16}$, Sophia Stoecklein, $\mathrm{MD}^{1}$, Olaf Dietrich $\mathrm{PhD}^{1}$, Peter Bartenstein, $\mathrm{MD}^{2,11}$, Johannes Levin, $\mathrm{MD}^{5,6,11}$, Günter Höglinger, $\mathrm{MD}^{5,8}$ and Robert Perneczky, MD, MBA $3,5,10,11,15$

${ }^{1}$ Department of Radiology, University Hospital, LMU Munich, Munich, Germany

${ }^{2}$ Department of Nuclear Medicine, University Hospital, LMU Munich, Munich, Germany

${ }^{3}$ Department of Psychiatry and Psychotherapy, University Hospital, LMU Munich, Munich, Germany

${ }^{4}$ Institute for Stroke and Dementia Research, University Hospital, LMU Munich, Munich, Germany

${ }^{5}$ German Center for Neurodegenerative Diseases (DZNE) Munich, Munich, Germany

${ }^{6}$ Department of Neurology, University Hospital, LMU Munich, Munich, Germany

${ }^{7}$ Department of Psychiatry and Psychotherapy, Klinikum rechts der Isar, Technical University Munich, Munich, Germany

${ }^{8}$ Department of Neurology, Hannover Medical School, Hannover, Germany

${ }^{9}$ Chair of Metabolic Biochemistry, Biomedical Center (BMC), Faculty of Medicine, LMU NOTE: This preprint reports new research that has not been certified by peer review and should not be used to guide clinical practice. Munich, Munich, Germany 
medRxiv preprint doi: https://doi.org/10.1101/2022.02.22.22271354; this version posted February 24, 2022. The copyright holder for this preprint (which was not certified by peer review) is the author/funder, who has granted medRxiv a license to display the preprint in It is made available under a CC-BY-NC-ND 4.0 International license.

${ }^{10}$ Ageing Epidemiology (AGE) Research Unit, School of Public Health, Imperial College London, London, UK

${ }^{11}$ Munich Cluster for Systems Neurology (SyNergy), Munich, Germany

${ }^{12}$ Department of Psychiatry, Psychotherapy and Psychosomatics, University of Augsburg, Bezirkskrankenhaus Augsburg, Augsburg, Germany

${ }^{13}$ Department of Psychiatry and Psychotherapy, University of Regensburg, Regensburg, Germany

${ }^{14}$ Department of Nuclear Medicine, University of Bern, Inselspital, Bern, Switzerland ${ }^{15}$ Sheffield Institute for Translational Neuroscience (SITraN), University of Sheffield, Sheffield, UK

${ }^{16}$ NeuroImaging Core Unit Munich (NICUM), University Hospital LMU, Munich, Germany

* Corresponding author:

Prof. Dr. Robert Perneczky

Division of Mental Health of Older Adults, Department of Psychiatry and Psychotherapy Ludwig-Maximilians-Universität München, Nußbaumstr. 7, 80336 Munich, Germany Tel.: +49 89 4400-53439, Fax: +49 89 4400-53411, Email: robert.perneczky@med.lmu.de 
medRxiv preprint doi: https://doi.org/10.1101/2022.02.22.22271354; this version posted February $24,2022$. The copyright holder for this preprint (which was not certified by peer review) is the author/funder, who has granted medRxiv a license to display the preprint in It is made available under a CC-BY-NC-ND 4.0 International license .

\begin{abstract}
Background: Alzheimer's disease (AD) is characterized by amyloid- $\beta(\mathrm{A} \beta)$ plaques, neurofibrillary tau tangles and neuroinflammation leading to brain functional connectivity changes and cognitive decline. There is evidence, that microglial activity is increased in AD and cognitive decline. $A \beta$ and tau pathology appear to spread along pathways of highly connected brain regions, but it remains elusive if microglial activation follows a similar distribution pattern.
\end{abstract}

Methods: Thirty-two early AD subjects and 18 age-matched healthy cognitively normal controls were included from the prospective ActiGliA study. Differences between the diagnostic groups were explored for translocator protein (TSPO) positron emission tomography (PET) microglial activation, diffusion tensor imaging (DTI) structural connectivity and magnetic resonance imaging (MRI) functional connectivity. Associations between PET microglial activation with cognitive impairment, dementia severity and MRI connectivity measures were investigated within the diagnostic groups.

Results: AD patients showed increased TSPO PET tracer uptake bilaterally in the parahippocampal region compared to cognitively normal controls. Higher TSPO PET was associated with cognitive impairment and dementia severity in a disease stage dependent fashion. Inter-regional covariance in TSPO PET and standardized uptake value ratio (SUVR) was found to be preferentially distributed along functionally highly connected brain regions, with MRI structural connectivity showing a weaker association with microglial activation. Conclusion: Neuroinflammation in AD is associated with clinical disease presentation, and like tau pathology, microglial activation seems to spread preferentially along highly connected brain regions. These findings support the important role of microglia in neurodegeneration and suggest that disease spreading throughout the brain along vulnerable connectivity pathways could guide future interventional anti-inflammatory therapy approaches to prevent disease progression. 
medRxiv preprint doi: https://doi.org/10.1101/2022.02.22.22271354; this version posted February 24, 2022. The copyright holder for this preprint (which was not certified by peer review) is the author/funder, who has granted medRxiv a license to display the preprint in It is made available under a CC-BY-NC-ND 4.0 International license

Keywords: Resting state fMRI, DTI, neuroinflammation, TSPO PET, neurodegeneration, prospective clinical cohort. 
medRxiv preprint doi: https://doi.org/10.1101/2022.02.22.22271354; this version posted February 24,2022 . The copyright holder for this preprint (which was not certified by peer review) is the author/funder, who has granted medRxiv a license to display the preprint in It is made available under a CC-BY-NC-ND 4.0 International license .

\section{Introduction}

Extracellular amyloid- $\beta(\mathrm{A} \beta)$ plaques and intracellular neurofibrillary tau tangles are the pathological hallmarks of Alzheimer's disease (AD), leading to a cascade of brain changes resulting in cognitive decline and dementia (Hardy and Higgins 1992). Recent genetic, molecular and clinical evidence suggests that neuroimmune mechanisms are associated with AD risk and contribute to disease progression (Calsolaro and Edison 2016; Heneka et al. 2015). Patients with symptomatic AD show alterations in cerebrospinal fluid (CSF) and blood pro- and anti-inflammatory proteins (Rauchmann et al. 2020; Rauchmann et al. 2019), including the soluble triggering receptor expressed on myeloid cells 2 (sTREM2), a marker of activated microglia (Shen et al. 2019), which typically surround A $\beta$ plaques as the brain's main innate immune response (Itagaki et al. 1989). This suggests that neuroinflammation and microglial activation plays a key role in the pathogenesis of AD.

In vivo, microglial activation can be measured with positron emission tomography (PET) tracers targeting the $18 \mathrm{kDa}$ translocator protein (TSPO), located on the outer mitochondrial membrane and overexpressed on activated immune cells (Edison and Brooks 2018). Increased microglial activation is apparent on TSPO PET scans in different neurodegenerative disorders, including $\mathrm{AD}$, corticobasal syndrome and progressive supranuclear palsy (Heneka et al. 2015; Knezevic and Mizrahi 2018; Palleis et al. 2021).

Neuroinflammation, extracellular $A \beta$ plaques and intracellular tau neurofibrils seem to be linked closely. Within the microglia population, two distinct expression profiles were recently identified, associated with either $A \beta$ load or tissue phosphorylated tau (ptau) (Gerrits et al. 2021). Colocalization of tau and activated microglia was demonstrated (Hayes et al. 2002; Dani et al. 2018), and A $\beta$ plaque-dependent microglia was identified (Plescher et al. 2018). Furthermore, TSPO PET binding was shown to correlate with increasing A $\beta$ accumulation in AD mouse models (Blume et al. 2018), and microglial activation may also act as a link between $A \beta$ and tau pathology (Kitazawa et al. 2004). 
medRxiv preprint doi: https://doi.org/10.1101/2022.02.22.22271354; this version posted February $24,2022$. The copyright holder for this preprint (which was not certified by peer review) is the author/funder, who has granted medRxiv a license to display the preprint in It is made available under a CC-BY-NC-ND 4.0 International license .

Several studies in AD have demonstrated that changes in functional magnetic resonance imaging (fMRI) connectivity are associated with hallmark protein aggregations. Highly connected hub regions show increased tau accumulation on PET imaging, accelerated by A $\beta$ pathology (Franzmeier et al. 2020; Vogel et al. 2020), supporting a model of transneuronal spread of tau molecules (Cope et al. 2018). Increasing evidence indicates that the spread of tau tangles in the neocortex is accompanied by microglial activation (Sheffield et al. 2000; Hopp et al. 2018; Dani et al. 2018), with both types of pathology seemingly following a Braak-stage-like distribution pattern along an activated network of microglia, suggesting that $A \beta$ and microglia together initiate tau spreading across the brain (Pascoal et al. 2021; Braak et al. 2006).

The main aims of the present study were to characterize the pattern of TSPO-PET microglial activation in early AD stages vs cognitively normal controls, to explore the associations between activated microglia and clinical endpoints, and to identify the brain structural and functional network connectivity correlates of the activated immune system. We used data from the prospective Activity of Cerebral Networks, Amyloid and Microglia in Aging and Alzheimer's disease (ActiGliA) study to address our hypotheses.

\section{Methods}

\section{Study design and participants}

The data used in this study originate from the baseline dataset of the ActiGliA study, a prospective, longitudinal, observational, single-center study of the Munich Cluster for Systems Neurology (SyNergy) at Ludwig-Maximilians-University (LMU) Munich, initiated in 2017. Participants were recruited through specialized outpatient clinics at the LMU hospital Department of Psychiatry and Psychotherapy, Department of Neurology and Institute of Stroke and Dementia Research and the Department of Psychiatry and Psychotherapy of the Technical University Munich. ActiGliA comprises comprehensive neurocognitive, clinical 
medRxiv preprint doi: https://doi.org/10.1101/2022.02.22.22271354; this version posted February 24,2022 . The copyright holder for this preprint (which was not certified by peer review) is the author/funder, who has granted medRxiv a license to display the preprint in It is made available under a CC-BY-NC-ND 4.0 International license .

and lifestyle assessments based on the German Center for Neurodegenerative Disorders (DZNE)-Longitudinal Cognitive Impairment and Dementia (DELCODE) study (Jessen et al. 2018); MRI and PET imaging using tracers for A $\beta$ and TSPO; and fluid biobanking, including CSF, plasma, serum, saliva, DNA, RNA and peripheral blood mononuclear cells. Patients with early AD (subjective cognitive impairment, MCI and mild AD dementia) and corticobasal syndrome (CBS) (Schmitt et al. 2021) and age-matched cognitively normal controls were included after providing written informed consent in line with the declaration of Helsinki. The study was approved by the ethics committee of LMU Munich (project numbers 17-755 and 17-569).

Out of 140 ActiGliA participants, all consecutive cases meeting the inclusion criteria for the present analyses were included, resulting in a cohort of $\mathrm{N}=32$ early $\mathrm{AD}$ patients and $\mathrm{N}=18$ cognitively normal controls. $\mathrm{N}=90$ participants were not considered for the present analysis due to a diagnosis of $\mathrm{N}=50 \mathrm{CBS}$ or other non-AD disorder $(\mathrm{N}=23)$. $\mathrm{N}=16$ participants were excluded because of missing neuropsychological test results and $\mathrm{N}=1$ participant was excluded because of extensive white matter lesions (Figure 1). Cognitive normal controls (CN) were defined as participants without cognitive impairment (Clinical Dementia Rating $(\mathrm{CDR})$ global score $=0$, Consortium to Establish a Registry for AD neuropsychological battery $($ CERAD-NB) total score $\geq 69)($ Chandler et al. 2005) and no indication of A $\beta$ pathology on PET (negative visual read) and/or CSF examination (normal A $\beta 42 / 40$-ratio as defined below). AD continuum was defined as CDR global score $\geq 0.5$, CERAD-NB total score $\leq 84$ and presence of $\mathrm{A} \beta$ pathology on PET and/or CSF examination.

\section{Clinical assessments}

The CDR, CERAD-NB (Fillenbaum et al. 2008) and Mini-Mental State Examination (MMSE) (Folstein et al. 1975) were conducted by trained psychologists at the LMU hospital memory clinic. Using the CERAD-NB battery a total score was created as shown previously, 
medRxiv preprint doi: https://doi.org/10.1101/2022.02.22.22271354; this version posted February 24, 2022. The copyright holder for this preprint (which was not certified by peer review) is the author/funder, who has granted medRxiv a license to display the preprint in It is made available under a CC-BY-NC-ND 4.0 International license .

comprising the six sub-tests semantic fluency (animals/60 seconds), modified Boston Naming Test, Word List Learning, Constructional Praxis, Word List Recall and Word List Recognition Discriminability, with higher scores indicating better performance $\underline{\text { Chandler et }}$ al. 2005).

\section{Genetic polymorphisms}

$T S P O$ and apolipoprotein E (APOE) genotyping was performed at the Departments of Psychiatry and Psychotherapy of University of Regensburg and LMU Munich respectively. Genomic DNA was extracted from whole blood using a SQ Blood DNA kit from Omega BioTek (Norcross, GA, USA) according to the manufacturer's protocol. DNA quality was assessed by optical absorbance and gel electrophoresis. TaqMan quantitative polymerase chain reaction assays were used for amplification and Sanger method for sequencing.

Binding affinity of the $\left[{ }^{18} \mathrm{~F}\right] \mathrm{GE}-180 \mathrm{TSPO}$ ligand is affected by the co-dominant rs6971 (Ala/Thr) single nucleotide polymorphisms (SNP) of the TSPO gene and needs to be considered in the imaging analysis (Kreisl et al. 2013). High-affinity binders (HAB) are Ala/Ala carriers, low-affinity binders (LAB) are Thr/Thr carriers and mixed-affinity binders (MAB) are Ala/Thr carriers. Only HAB and MAB carriers were included in the PET analyses, with $\mathrm{N}=6$ LAB excluded. All TSPO PET analyses were adjusted for binding status. The two SNPs rs429358 and rs7412 defining the $A P O E \varepsilon 2, \varepsilon 3$ and $\varepsilon 4$ alleles were analyzed to determine the $A P O E$ genotype. Sequencing data were analyzed using SnapGene software (GSL Biotech; http://snapgene.com). Participants were dichotomized into carriers vs noncarriers of the $\varepsilon 4$ allele.

\section{CSF analyses}

CSF peptide measures were generated from aliquoted samples using commercially available (Fujirebio, Malvern, PA) enzyme-linked immunosorbent assays (ELISAs). A $\beta$ positivity was 
medRxiv preprint doi: https://doi.org/10.1101/2022.02.22.22271354; this version posted February $24,2022$. The copyright holder for this preprint (which was not certified by peer review) is the author/funder, who has granted medRxiv a license to display the preprint in It is made available under a CC-BY-NC-ND 4.0 International license .

defined as a CSF A $\beta 42 / 40$-ratio of $<5.5 \%$, as suggested previously (Dumurgier et al. 2015). Concentrations of total tau (ttau) and ptau181 were measured in CSF using the Innotest htauAg, and Innotest P-tau (181P) ELISA assays (Fujirebio, Europe). The CSF sTREM2 concentrations were measured at the DZNE Munich based on previously established in-house ELISA protocols using duplicate samples (Suárez-Calvet et al. 2016). Average measurements of the duplicates were used for the statistical analyses after applying method and platespecific correction procedures.

\section{MRI acquisition and preprocessing}

MRI data for the entire ActiGliA cohort was acquired at the Department of Radiology of LMU Munich on a Siemens 3T Magnetom Skyra MR system (Siemens Healthineers, Erlangen, Germany). A $0.8 \mathrm{~cm}$ isovoxel high resolution T1-weighted structural MRI sequence (repetition time (TR), 2060 ms; echo time (TE), $2.17 \mathrm{~ms}$; flip angle (FA), $12 \mathrm{deg}$; field of view (FoV), $240 \mathrm{~mm}$ ), a diffusion weighted imaging (DWI) MRI sequence with a multi-band acceleration factor 3 (TR, $3800 \mathrm{~ms}$; TE, $104.8 \mathrm{~ms}$; b-value, $2000 \mathrm{~s} / \mathrm{mm}^{2} ; 108$ diffusion directions; FA, $90 \mathrm{deg}$, FoV, $240 \mathrm{~mm}$ ) and a $2.5 \mathrm{~mm}, 10: 32 \mathrm{~min}$ resting state fMRI sequence with multi-band acceleration factor 6 (TR, $780 \mathrm{~ms}$; TE, $33 \mathrm{~ms}$; FA, $50 \mathrm{deg}$; FoV, $210 \mathrm{~mm}$ ) were acquired.

Resting state functional connectivity was analyzed using the CONN fMRI functional connectivity toolbox (ver. 17, www.nitrc.org/projects/conn) in MATLAB (MathWorks, Inc., Natick, Massachusetts, USA). Preprocessing comprised visual inspection, volume-based fMRI analyses, including realignment, slice-time correction, segmentation and structural and functional normalization, ART-based outlier detection and functional smoothing using a 6 mm kernel. The pipeline details can be found elsewhere (https://web.conn-toolbox.org/fmrimethods/preprocessing-pipeline).

All diffusion tensor imaging (DTI) images were visually inspected. Preprocessing was 
medRxiv preprint doi: https://doi.org/10.1101/2022.02.22.22271354; this version posted February $24,2022$. The copyright holder for this preprint (which was not certified by peer review) is the author/funder, who has granted medRxiv a license to display the preprint in It is made available under a CC-BY-NC-ND 4.0 International license .

performed using ExploreDTI (Leemans et al. 2009), a MATLAB (MathWorks, Inc., Natick, Massachusetts, USA) toolbox, including motion correction and eddy current correction and correction for echo planar imaging (EPI) distortions.

\section{Positron emission tomography acquisition and preprocessing}

Patients were scanned at the Department of Nuclear Medicine of LMU Munich on a Biograph 64 PET/CT scanner (Siemens Healthineers, Erlangen, Germany). Prior to PET acquisition a low-dose CT scan was acquired for attenuation correction. Emission data were acquired dynamically over 90 min or static from $60-80$ min p.i., starting with the injection of $189 \pm 12$ $\mathrm{MBq}\left[{ }^{18} \mathrm{~F}\right] \mathrm{GE}-180$ as an intravenous bolus. The specific activity was on average $1.714 \pm 523$ $\mathrm{GBq} / \mu \mathrm{mol}$ at the end of radiosynthesis, and the injected mass was $0.13 \pm 0.05 \mathrm{nmol}$ (based on $\mathrm{N}=5$ syntheses). Images were reconstructed using a 3-dimensional ordered subsets expectation maximization algorithm (16 iterations, 4 subsets, $4 \mathrm{~mm}$ gaussian filter) with a matrix size of $336 \times 336 \times 109$, and a voxel size of $1.018 \times 1.018 \times 2.027 \mathrm{~mm}$. Standard corrections for attenuation, scatter, decay and random counts were applied.

TSPO PET scans were co-registered to the subject's individual T1-weighted structural MRI scan, skull-stripped using FSL BET. Non-linear spatial normalization parameters to the Montreal Neurological Institute (MNI) standard space were estimated using Advanced Normalization Tools (ANTs). The obtained spatial normalization parameter estimations were subsequently used to normalize the TSPO PET scan to the MNI space. To obtain standardized uptake value ratios (SUVRs), the TSPO PET scans were intensity normalized using the inferior cerebellar grey matter as reference region (Baker et al. 2017).

\section{Analysis of TSPO PET differences between diagnostic groups}

Differences between the diagnostic groups were estimated in a voxel-wise analysis using SPM12 (The Wellcome Centre for Human Neuroimaging, London, UK). MNI normalized 
medRxiv preprint doi: https://doi.org/10.1101/2022.02.22.22271354; this version posted February $24,2022$. The copyright holder for this preprint (which was not certified by peer review) is the author/funder, who has granted medRxiv a license to display the preprint in It is made available under a CC-BY-NC-ND 4.0 International license .

TSPO PET images were spatially smoothed using an $8 \mathrm{~mm}$ FWHM kernel. In an atlas-based analysis the individual TSPO tracer uptake was calculated in the regions of the Brainnetome atlas, a multimodal connectivity based parcellation framework atlas based on a 246-region brain parcellation, including 210 cortical and 36 subcortical subregions (Fan et al. 2016).

Analysis of the structural and functional connectomes and their associations with TSPO PET covariance

The Brainnetome atlas was used to determine the individual in vivo connectivity architecture when assessing structural and functional connectivity. Group differences in functional and structural connectivity between $\mathrm{AD}$ and control subjects were assessed using the CONN toolbox and GraphVar (Kruschwitz et al. 2015). The associations between TSPO PET tracer uptake and functional and structural connectivity were analyzed using in-house MATLAB scripts for z-scaling, covariance calculation and linear regression analysis.

\section{Statistical analyses}

Group differences in functional connectivity were tested in a general linear model using individual adjacency matrices of the Brainnetome atlas based 246 regions parcellation in a region of interest (ROI)-to-ROI analysis in the CONN toolbox. All results were adjusted for age, sex and education with false discovery rate (FDR) correction for multiple comparisons with a significance level of $p<0.05$. Differences in structural connectivity between the diagnostic groups were tested in a general linear model using the individual DTI derived adjacency matrices of the number of tracts comprising the $246 \mathrm{BN}$ atlas-based regions in the GraphVar toolbox adjusted for age, sex and education. Associations between clinical scores and TSPO PET uptake was tested using a quadratic regression analysis in SPSS (IBM SPSS Statistics for Windows, Version 26.0. Armonk, NY: IBM Corp) assuming a disease stagedependent microglial activation pattern, as shown previously (Blume et al. 2018). 
medRxiv preprint doi: https://doi.org/10.1101/2022.02.22.22271354; this version posted February $24,2022$. The copyright holder for this preprint (which was not certified by peer review) is the author/funder, who has granted medRxiv a license to display the preprint in It is made available under a CC-BY-NC-ND 4.0 International license .

To assess the association between MRI functional/structural connectivity and microglial activation on PET, the Fisher r-to-z transformed matrices of functional connectivity and the z-transformed DTI-derived number of tracts matrices for each subject were used. First, the Brainnetome atlas-based TSPO PET SUVR for each subject was concatenated, vectorized and z-transformed to remove inter-subject differences of the tracer uptake (Veronese et al. 2019), followed by a pairwise interregional correlation to calculate a TSPO PET covariance adjacency matrix for each diagnostic group. We vectorized the TSPO PET covariance matrix and the mean functional and structural connectivity adjacency matrices and performed a linear regression analysis to predict TSPO PET covariance from connectivity. Due to skewed distribution the vectorized structural connectivity was logtransformed for further analysis, not connected brain regions were excluded. Second, we tested how depending on the TSPO PET uptake in a seed region connectivity was associated with TSPO PET uptake in the target regions. To this end, we first calculated the mean adjacency matrix of functional and structural connectivity, followed by correlating each mean matrix with the TSPO SUVR vector to obtain a correlation vector. Subsequently, in a linear regression analysis we tested how the TSPO PET SUVRs were associated with the correlation vectors between functional/structural connectivity and TSPO SUVR. Finally, the association between TSPO PET uptake in functional/structural connectivity target regions and the functional/structural connectivity in hotspot and cold spot seed areas of TSPO PET uptake were assessed. The mean SUVR TSPO uptake was sorted discerningly in all $246 \mathrm{BN}$ regions for each diagnostic group to define a hot and a cold spot region. Subsequently, in consequent regression analyses the TSPO PET uptake in all target regions was predicted by the functional/structural connectivity of the hotspot and cold spot.

\section{Results}

Differences in sociodemographic and clinical data between the diagnostic groups are 
medRxiv preprint doi: https://doi.org/10.1101/2022.02.22.22271354; this version posted February $24,2022$. The copyright holder for this preprint (which was not certified by peer review) is the author/funder, who has granted medRxiv a license to display the preprint in

It is made available under a CC-BY-NC-ND 4.0 International license .

presented in Table 1. There were no differences in age, sex, weight and years of education. Compared to cognitively normal controls, AD subjects had significantly $(\mathrm{p}<0.001)$ worse cognitive performance (CERAD-NB and MMSE) and higher CDR-sob ratings. As expected, AD patients showed more pathological CSF biomarker concentrations compared to the control group (lower $A \beta 42$ and $A \beta 42 / 40$-ratio, higher ptau181 and ttau).

\section{Group differences on PET and MRI}

Supporting the view of increased microglial activation in AD, the AD patient group showed increased TSPO PET tracer uptake compared to cognitively normal controls $(\mathrm{p}<0.001)$ in the bilateral parahippocampal gyrus (Table 2, Figure 2A). Group differences in functional connectivity were detected on the whole brain level and within the default mode network comparing cognitively normal controls and $\mathrm{AD}$ patients. On the whole brain level, a widespread hypoconnectivity in $\mathrm{AD}$ with some hyperconnectivity mainly between temporal and cingulate/occipital and frontal brain regions was revealed (Figure 2B). Within the default mode network hypoconnectivity between bilateral hippocampal regions was observed in AD

(Supplementary Figure 1). No significant differences were detected in the visual dorsal attention ventral attention limbic and frontotemporal networks. A widespread hyperconnectivity pattern was revealed in the structural connectivity analysis with partial hyperconnectivity mainly between temporooccipital and temporoparietal regions (Figure 2C).

Associations between TSPO PET, dementia severity and cognitive performance

We analyzed how TSPO tracer uptake in the parahippocampal region was associated with dementia severity and cognitive impairment. Our analysis revealed a quadratic association, between parahippocampal TSPO PET SUVR and CDR sob $\left(\mathrm{R}^{2}=0.39, \mathrm{p}<0.001\right)$, CERAD-NB total score $\left(\mathrm{R}^{2}=0.20, \mathrm{p}<0.017\right)$ and MMSE score $\left(\mathrm{R}^{2}=0.15, \mathrm{p}=0.049\right)$ (Figure 3). 
medRxiv preprint doi: https://doi.org/10.1101/2022.02.22.22271354; this version posted February $24,2022$. The copyright holder for this preprint (which was not certified by peer review) is the author/funder, who has granted medRxiv a license to display the preprint in It is made available under a CC-BY-NC-ND 4.0 International license .

\section{Associations between functional and structural connectivity and TSPO PET}

We assessed how TSPO PET microglial activation is associated with functional and structural connectivity in AD patients and cognitively normal controls. Adjacency matrices of functional and structural connectivity using the 246 Brainnetome regions were generated for the control and $\mathrm{AD}$ patient groups (Figure 4B and Figure 4C). Using the same regions, TSPO PET derived covariance matrices were calculated for cognitively normal controls and AD patients (Figure 4A). In a subsequent regression analysis, the associations between functional and structural connectivity with TSPO PET tracer uptake covariance were assessed. A significant association between functional connectivity and TSPO PET covariance was revealed in the $\mathrm{AD}(\beta=0.35, \mathrm{p}<0.001)$ and in the control group $(\beta=0.47$, $\mathrm{p}<0.001$ ) (Figure 5A). For structural connectivity, a weak association with TSPO PET covariance was shown for cognitively normal controls $(\beta=0.08 ; \mathrm{p}<0.001)$ and for AD patients $(\beta=0.06 ; p<0.001)$ (Figure 5B). Log-transformed data were reported because of skewed distribution.

\section{Network connectivity prediction of TSPO PET tracer uptake}

We explored if TSPO PET tracer uptake in a particular region is predictive of the TSPO levels in a connected region, following a similar approach proposed recently for the association between functional connectivity and tau PET (Franzmeier et al. 2019). For seed regions with higher levels of TSPO PET uptake functional connectivity was associated with higher levels of TSPO PET uptake in the target regions and vice versa in the cognitively normal controls $(\beta=0.57, \mathrm{p}<0.001)$ and the $\mathrm{AD}$ group $(\beta=0.83, \mathrm{p}<0.001)$ (Figure 6A). A somewhat weaker association was shown for structural connectivity in cognitively normal controls $(\beta=0.37$, $\mathrm{p}<0.001)$ and $\mathrm{AD}$ patients $(\beta=0.36, \mathrm{p}<0.001)$ (Figure 6B).

We analyzed how functional connectivity in seed regions with high TSPO PET uptake 
medRxiv preprint doi: https://doi.org/10.1101/2022.02.22.22271354; this version posted February $24,2022$. The copyright holder for this preprint (which was not certified by peer review) is the author/funder, who has granted medRxiv a license to display the preprint in

It is made available under a CC-BY-NC-ND 4.0 International license .

and in seed regions with low TSPO uptake was associated with the TSPO PET uptake in all target regions. The hot spot seed regions analysis revealed strong positive associations in cognitively normal controls $(\beta=0.79, \mathrm{p}<0.001)$ and AD patients $(\beta=0.74, \mathrm{p}<0.001)$, whereas in the cold spot seed regions analyses a negative association was shown for both groups (cognitively normal controls: $\beta=0.22, \mathrm{p}<0.03$; AD patients: $\beta=0.25, \mathrm{p}=0.002$ ) (Figure 7A). The same analysis based on structural connectivity did not reveal any significant positive or negative associations (Figure 7B).

\section{Discussion}

Microglial activation is increasingly considered the third pathological hallmark of AD, in addition to $A \beta$ and tau (Kinney et al. 2018). The main findings of this study are that (i) in early $\mathrm{AD}$ vs cognitively normal controls microglial activation is increased in the temporal lobe (more precisely, the bilateral parahippocampal gyrus), (ii) functional and structural connectivity are reduced globally in $\mathrm{AD}$ accompanied by several brain regions showing hyperconnectivity, (iii) microglial activation is associated with dementia severity and cognitive impairment in a disease stage-dependent manner, (iv) functional (and to a lesser degree structural) connectivity is associated with activated microglia and (v) microglial activation spreads along pathways of highly connected brain regions (functional $>$ structural) similar to tau.

Our first finding showed increased parahippocampal microglial activation in AD. This is in line with several previous studies reporting early neurodegenerative and inflammatory changes in the medial temporal lobe (Hamelin et al. 2016; Su et al. 2021; Khan et al. 2014), overlapping with the earliest sites of tau pathology accumulation (Braak et al. 2006). We also confirm the association between dementia severity and cognitive impairment with microglial activation, reported in previous research (Su et al. 2021). The observed quadratic association revealed in the present study indicates a disease stage-dependence of neuroinflammatory 
medRxiv preprint doi: https://doi.org/10.1101/2022.02.22.22271354; this version posted February 24,2022 . The copyright holder for this preprint (which was not certified by peer review) is the author/funder, who has granted medRxiv a license to display the preprint in It is made available under a CC-BY-NC-ND 4.0 International license .

response across the AD continuum, earlier suggested for sTREM2, another marker of microglial activation with an inverse $\mathrm{u}$-shaped association between AD severity and CSF sTREM2 levels (Suárez-Calvet et al. 2019; Suárez-Calvet et al. 2016). For TSPO PET this stage dependent association was also observed in a mouse model overexpressing the $A \beta$ precursor protein (Blume et al. 2018). Our study revealed a trend for associations with sTREM2, failing to meet statistical significance due to the relatively small sample size.

Previous research indicates that microglial activation is related to tau propagation and colocalizes with tau pathology in a Braak stage-like fashion; furthermore, activated microglia has been found to precede tau pathology (Hopp et al. 2018; Serrano-Pozo et al. 2011; Pascoal et al. 2021). Although the present study did not explore directly the spatial colocalization of microglial and tau tracer uptake on PET, the Braak stage-like pattern of neuroinflammatory response in early AD still suggest a close relation between both pathologies. In support of this hypothesis a recent multimodal study suggested a strong spatial overlap between tau and microglial PET as well as gray matter atrophy (Su et al. 2021).

The main goal of this study was to assess if functional and structural connectivity are associated with activated microglia. A growing body of evidence supports a model of prionlike tau spreading with progressing neurodegeneration, presumably promoted by neural activity (Franzmeier et al. 2019; Franzmeier et al. 2020; Pereira et al. 2019). In this study, we demonstrated that not only tau, but also microglial activation follows a distribution along functional, and to a lesser degree also structural, connectivity pathways, in line with spatial pathological colocalization. We report that brain areas with higher microglial activation show increased functional connectivity within the same region and with other regions with activated microglia.

We also observed that regions with low microglial activation showed decreased functional connectivity, supporting the hypothesis that not only tau but also activated microglial spread along functionally connected brain areas. Since we observed weaker 
medRxiv preprint doi: https://doi.org/10.1101/2022.02.22.22271354; this version posted February 24,2022 . The copyright holder for this preprint (which was not certified by peer review) is the author/funder, who has granted medRxiv a license to display the preprint in It is made available under a CC-BY-NC-ND 4.0 International license .

associations for structural connectivity, one could argue that regions of neuroinflammation are connected by neural activity rather than simply by structural connections.

The described distribution patterns of microglial activation may be of great value for the development of possible anti-inflammatory treatments. They also highlight the importance of an improved mechanistic understanding of spatial spreading of different pathologies across the brain, not limited to $A \beta$ and tau. Strategies to reduce the neural activity-dependent propagation of $\mathrm{AD}$ pathology may be a promising avenue for future disease-modifying interventions. It remains to be shown that tau is the leading factor in this process of connectivity-dependent pathology spreading across the brain, followed by a reactive activation of microglia in the same regions. Microglia phagocytose tau and therefore play an important role in spreading of tau pathology throughout the brain (Vogels et al. 2019). There is also evidence that an interaction between microglial activation and $\mathrm{A} \beta$ triggers the dissemination of tau across the Braak stages (Pascoal et al. 2021). Further studies including tau and microglia PET should address the question of possible differences in the sequence of tau and inflammation distribution.

There are potential limitations of this study. A relatively small sample size restricts the statistical power of some of the analyses, but previous studies relied on cohorts of comparable size (Völk et al. 2020) and the nature of the presented data is of explorative nature and should be confirmed in independent datasets. No pathological verification was available to confirm the clinical diagnoses; however, a careful biomarker-based stratification and in-depth phenotyping minimizes the likelihood of diagnostic misclassification. Limited blood-brainbarrier passing of $\left[{ }^{18} \mathrm{~F}\right] \mathrm{GE}-180$ needs to be acknowledged, but our previous data indicated strong agreement with immunohistochemistry in AD models (Parhizkar et al. 2019) and patterns matching known topology of microglial activation in neurodegenerative diseases (Xiang et al. 2021; Palleis et al. 2021). In fact, the low background signal of $\left[{ }^{18} \mathrm{~F}\right] \mathrm{GE}-180$ appears to facilitate sensitive detection of alterations as a specific surrogate of microglial 
medRxiv preprint doi: https://doi.org/10.1101/2022.02.22.22271354; this version posted February 24, 2022. The copyright holder for this preprint (which was not certified by peer review) is the author/funder, who has granted medRxiv a license to display the preprint in

It is made available under a CC-BY-NC-ND 4.0 International license .

activation (Sridharan et al. 2019; Biechele et al. 2021; Ewers et al. 2020). AD patients were predominantly in an early disease stage, and group differences of microglial activation may have been diluted in the cross-sectional analysis if several activity peaks exist as AD progresses (Fan et al. 2017).

To conclude, the results of this study suggest that microglia-related neuroinflammation in AD spreads along highly connected brain regions. It remains to be explored if this pattern reflects a consequence of trans-neuronal tau spreading or if neuroinflammation itself promotes tau distribution. We confirm that clinical AD is affected by neuroinflammation, and our findings raise the important question if anti-inflammatory treatments could modify trans-neural transmission, emphasizing the need for further comprehensive research integrating mechanisms on the molecular and macro scale brain network levels.

\section{Acknowledgement}

The authors thank Christian Haass, $\mathrm{PhD}$ for his support.

This study was supported by the German Center for Neurodegenerative Disorders (Deutsches Zentrum für Neurodegenerative Erkrankungen, DZNE), the Hirnliga e.V. (Manfred-

Strohscheer Stiftung) and the Deutsche Forschungsgemeinschaft (DFG, 1007 German Research Foundation) under Germany's Excellence Strategy within the framework of 1008 the Munich Cluster for Systems Neurology (EXC 2145 SyNergy - ID 390857198).

\section{References}

Arevalo-Rodriguez, Ingrid, Nadja Smailagic, Marta Roqué I Figuls, Agustín Ciapponi, Erick Sanchez-Perez, Antri Giannakou, Olga L. Pedraza, Xavier Bonfill Cosp, and Sarah Cullum. 2015. "Mini-Mental State Examination (MMSE) for the Detection of Alzheimer's Disease and Other Dementias in People with Mild Cognitive Impairment (MCI)." Cochrane Database 
medRxiv preprint doi: https://doi.org/10.1101/2022.02.22.22271354; this version posted February 24, 2022. The copyright holder for this preprint (which was not certified by peer review) is the author/funder, who has granted medRxiv a license to display the preprint in It is made available under a CC-BY-NC-ND 4.0 International license .

of Systematic Reviews, no. 3 (March): CD010783.

Asai, Hirohide, Seiko Ikezu, Satoshi Tsunoda, Maria Medalla, Jennifer Luebke, Tarik Haydar, Benjamin Wolozin, Oleg Butovsky, Sebastian Kügler, and Tsuneya Ikezu. 2015. "Depletion of Microglia and Inhibition of Exosome Synthesis Halt Tau Propagation.” Nature Neuroscience 18 (11): 1584-93.

Baker, Suzanne L., Anne Maass, and William J. Jagust. 2017. "Considerations and Code for Partial Volume Correcting [18F]-AV-1451 Tau PET Data.” Data in Brief 15 (December): $648-57$.

Blume, Tanja, Carola Focke, Finn Peters, Maximilian Deussing, Nathalie L. Albert, Simon Lindner, Franz-Josef Gildehaus, et al. 2018. "Microglial Response to Increasing Amyloid Load Saturates with Aging: A Longitudinal Dual Tracer in Vivo $\mu$ PET-Study.” Journal of Neuroinflammation 15 (1): 307.

Braak, Heiko, Irina Alafuzoff, Thomas Arzberger, Hans Kretzschmar, and Kelly Del Tredici. 2006. "Staging of Alzheimer Disease-Associated Neurofibrillary Pathology Using Paraffin Sections and Immunocytochemistry." Acta Neuropathologica 112 (4): 389-404.

Calsolaro, Valeria, and Paul Edison. 2016. "Neuroinflammation in Alzheimer's Disease: Current Evidence and Future Directions." Alzheimer's \& Dementia: The Journal of the Alzheimer's Association 12 (6): 719-32.

Chandler, M. J., L. H. Lacritz, L. S. Hynan, H. D. Barnard, G. Allen, M. Deschner, M. F. Weiner, and C. M. Cullum. 2005. "A Total Score for the CERAD-NB Neuropsychological Battery." Neurology 65 (1): 102-6.

Cope, Thomas E., Timothy Rittman, Robin J. Borchert, P. Simon Jones, Deniz Vatansever, Kieren Allinson, Luca Passamonti, et al. 2018. "Tau Burden and the Functional Connectome in Alzheimer's Disease and Progressive Supranuclear Palsy." Brain: A Journal of Neurology 141 (2): 550-67.

Dani, Melanie, Melanie Wood, Ruth Mizoguchi, Zhen Fan, Zuzana Walker, Richard Morgan, 
medRxiv preprint doi: https://doi.org/10.1101/2022.02.22.22271354; this version posted February 24, 2022. The copyright holder for this preprint (which was not certified by peer review) is the author/funder, who has granted medRxiv a license to display the preprint in It is made available under a CC-BY-NC-ND 4.0 International license .

Rainer Hinz, et al. 2018. "Microglial Activation Correlates in Vivo with Both Tau and Amyloid in Alzheimer's Disease." Brain: A Journal of Neurology 141 (9): 2740-54.

Dumurgier, Julien, Susanna Schraen, Audrey Gabelle, Olivier Vercruysse, Stéphanie Bombois, Jean-Louis Laplanche, Katell Peoc’h, et al. 2015. “Cerebrospinal Fluid Amyloid- $\beta$ 42/40 Ratio in Clinical Setting of Memory Centers: A Multicentric Study." Alzheimer's Research \& Therapy 7 (1): 30.

Edison, Paul, and David J. Brooks. 2018. "Role of Neuroinflammation in the Trajectory of Alzheimer's Disease and in Vivo Quantification Using PET." Journal of Alzheimer's Disease: JAD 64 (s1): S339-51.

Fan, Lingzhong, Hai Li, Junjie Zhuo, Yu Zhang, Jiaojian Wang, Liangfu Chen, Zhengyi Yang, et al. 2016. "The Human Brainnetome Atlas: A New Brain Atlas Based on Connectional Architecture." Cerebral Cortex 26 (8): 3508-26.

Fan, Zhen, David J. Brooks, Aren Okello, and Paul Edison. 2017. “An Early and Late Peak in Microglial Activation in Alzheimer's Disease Trajectory." Brain: A Journal of Neurology 140 (3): 792-803.

Fillenbaum, Gerda G., Gerald van Belle, John C. Morris, Richard C. Mohs, Suzanne S. Mirra, Patricia C. Davis, Pierre N. Tariot, et al. 2008. "Consortium to Establish a Registry for Alzheimer's Disease (CERAD-NB): The First Twenty Years." Alzheimer's \& Dementia: The Journal of the Alzheimer's Association 4 (2): 96-109.

Franzmeier, Nicolai, Julia Neitzel, Anna Rubinski, Ruben Smith, Olof Strandberg, Rik Ossenkoppele, Oskar Hansson, Michael Ewers, and Alzheimer's Disease Neuroimaging Initiative (ADNI). 2020. "Functional Brain Architecture Is Associated with the Rate of Tau Accumulation in Alzheimer's Disease.” Nature Communications 11 (1): 347.

Franzmeier, Nicolai, Anna Rubinski, Julia Neitzel, Yeshin Kim, Alexander Damm, Duk L. Na, Hee Jin Kim, et al. 2019. "Functional Connectivity Associated with Tau Levels in Ageing, Alzheimer's, and Small Vessel Disease.” Brain: A Journal of Neurology 142 (4): 
medRxiv preprint doi: https://doi.org/10.1101/2022.02.22.22271354; this version posted February 24, 2022. The copyright holder for this preprint (which was not certified by peer review) is the author/funder, who has granted medRxiv a license to display the preprint in It is made available under a CC-BY-NC-ND 4.0 International license .

$1093-1107$.

Hamelin, Lorraine, Julien Lagarde, Guillaume Dorothée, Claire Leroy, Mickael Labit, Robert A. Comley, Leonardo Cruz de Souza, et al. 2016. "Early and Protective Microglial Activation in Alzheimer's Disease: A Prospective Study Using 18F-DPA-714 PET Imaging.” Brain: A Journal of Neurology 139 (Pt 4): 1252-64.

Hayes, A., U. Thaker, T. Iwatsubo, S. M. Pickering-Brown, and D. M. A. Mann. 2002. "Pathological Relationships between Microglial Cell Activity and Tau and Amyloid Beta Protein in Patients with Alzheimer's Disease.” Neuroscience Letters 331 (3): 171-74. Heneka, Michael T., Monica J. Carson, Joseph El Khoury, Gary E. Landreth, Frederic Brosseron, Douglas L. Feinstein, Andreas H. Jacobs, et al. 2015. "Neuroinflammation in Alzheimer's Disease.” Lancet Neurology 14 (4): 388-405.

Hopp, Sarah C., Yang Lin, Derek Oakley, Allyson D. Roe, Sarah L. DeVos, David Hanlon, and Bradley T. Hyman. 2018. "The Role of Microglia in Processing and Spreading of Bioactive Tau Seeds in Alzheimer's Disease.” Journal of Neuroinflammation 15 (1): 269. Khan, Usman A., Li Liu, Frank A. Provenzano, Diego E. Berman, Caterina P. Profaci, Richard Sloan, Richard Mayeux, Karen E. Duff, and Scott A. Small. 2014. "Molecular Drivers and Cortical Spread of Lateral Entorhinal Cortex Dysfunction in Preclinical Alzheimer's Disease.” Nature Neuroscience 17 (2): 304-11.

Kinney, Jefferson W., Shane M. Bemiller, Andrew S. Murtishaw, Amanda M. Leisgang, Arnold M. Salazar, and Bruce T. Lamb. 2018. "Inflammation as a Central Mechanism in Alzheimer's Disease." Alzheimer's \& Dementia: The Journal of the Alzheimer's Association 4 (September): 575-90.

Kitazawa, Masashi, Tritia R. Yamasaki, and Frank M. LaFerla. 2004. "Microglia as a Potential Bridge between the Amyloid Beta-Peptide and Tau." Annals of the New York Academy of Sciences 1035 (December): 85-103.

Knezevic, Dunja, and Romina Mizrahi. 2018. "Molecular Imaging of Neuroinflammation in 
medRxiv preprint doi: https://doi.org/10.1101/2022.02.22.22271354; this version posted February 24, 2022. The copyright holder for this preprint (which was not certified by peer review) is the author/funder, who has granted medRxiv a license to display the preprint in It is made available under a CC-BY-NC-ND 4.0 International license .

Alzheimer's Disease and Mild Cognitive Impairment." Progress in NeuroPsychopharmacology \& Biological Psychiatry 80 (Pt B): 123-31.

Kreisl, William C., Kimberly J. Jenko, Christina S. Hines, Chul Hyoung Lyoo, Winston Corona, Cheryl L. Morse, Sami S. Zoghbi, et al. 2013. “A Genetic Polymorphism for Translocator Protein $18 \mathrm{kDa}$ Affects Both in Vitro and in Vivo Radioligand Binding in Human Brain to This Putative Biomarker of Neuroinflammation." Journal of Cerebral Blood Flow and Metabolism: Official Journal of the International Society of Cerebral Blood Flow and Metabolism 33 (1): 53-58.

Kruschwitz, J. D., D. List, L. Waller, M. Rubinov, and H. Walter. 2015. “GraphVar: A UserFriendly Toolbox for Comprehensive Graph Analyses of Functional Brain Connectivity." Journal of Neuroscience Methods 245 (April): 107-15.

Leemans, A., B. Jeurissen, J. Sijbers, and Derek K. Jones. 2009. “ExploreDTI: A Graphical Toolbox for Processing, Analyzing, and Visualizing Diffusion MR Data.” https://www.semanticscholar.org/paper/f92f4418d4a4523a5760414144ecce8ab6472fde. Palleis, Carla, Julia Sauerbeck, Leonie Beyer, Stefanie Harris, Julia Schmitt, Estrella Morenas-Rodriguez, Anika Finze, et al. 2021. "In Vivo Assessment of Neuroinflammation in 4-Repeat Tauopathies." Movement Disorders: Official Journal of the Movement Disorder Society 36 (4): 883-94.

Pascoal, Tharick A., Andrea L. Benedet, Nicholas J. Ashton, Min Su Kang, Joseph Therriault, Mira Chamoun, Melissa Savard, et al. 2021. "Microglial Activation and Tau Propagate Jointly across Braak Stages.” Nature Medicine, August. https://doi.org/10.1038/s41591-021-01456W.

Pereira, Joana B., Rik Ossenkoppele, Sebastian Palmqvist, Tor Olof Strandberg, Ruben Smith, Eric Westman, and Oskar Hansson. 2019. “Amyloid and Tau Accumulate across Distinct Spatial Networks and Are Differentially Associated with Brain Connectivity." eLife 8 (December): e50830. 
medRxiv preprint doi: https://doi.org/10.1101/2022.02.22.22271354; this version posted February 24, 2022. The copyright holder for this preprint (which was not certified by peer review) is the author/funder, who has granted medRxiv a license to display the preprint in It is made available under a CC-BY-NC-ND 4.0 International license .

Plescher, Monika, Gerald Seifert, Jan Niklas Hansen, Peter Bedner, Christian Steinhäuser, and Annett Halle. 2018. "Plaque-Dependent Morphological and Electrophysiological Heterogeneity of Microglia in an Alzheimer's Disease Mouse Model.” Glia 66 (7): 1464-80. Serrano-Pozo, Alberto, Matthew L. Mielke, Teresa Gómez-Isla, Rebecca A. Betensky, John H. Growdon, Matthew P. Frosch, and Bradley T. Hyman. 2011. "Reactive Glia Not Only Associates with Plaques but Also Parallels Tangles in Alzheimer's Disease.” The American Journal of Pathology 179 (3): 1373-84.

Sheffield, L. G., J. G. Marquis, and N. E. Berman. 2000. "Regional Distribution of Cortical Microglia Parallels that of Neurofibrillary Tangles in Alzheimer's Disease." Neuroscience Letters 285 (3): 165-68.

Shen, Xue-Ning, Li-Dong Niu, Yan-Jiang Wang, Xi-Peng Cao, Qiang Liu, Lan Tan, Can Zhang, and Jin-Tai Yu. 2019. "Inflammatory Markers in Alzheimer's Disease and Mild Cognitive Impairment: A Meta-Analysis and Systematic Review of 170 Studies." Journal of Neurology, Neurosurgery, and Psychiatry 90 (5): 590-98.

Suárez-Calvet, Marc, Gernot Kleinberger, Miguel Ángel Araque Caballero, Matthias Brendel, Axel Rominger, Daniel Alcolea, Juan Fortea, et al. 2016. "sTREM2 Cerebrospinal Fluid Levels Are a Potential Biomarker for Microglia Activity in Early-Stage Alzheimer's Disease and Associate with Neuronal Injury Markers.” EMBO Molecular Medicine 8 (5): 466-76. Suárez-Calvet, Marc, Estrella Morenas-Rodríguez, Gernot Kleinberger, Kai Schlepckow, Miguel Ángel Araque Caballero, Nicolai Franzmeier, Anja Capell, et al. 2019. “Early Increase of CSF sTREM2 in Alzheimer's Disease Is Associated with Tau RelatedNeurodegeneration but Not with Amyloid- $\beta$ Pathology.” Molecular Neurodegeneration 14 (1): 1 .

Su, Li, Ajenthan Surendranathan, Yujing Huang, William R. Bevan-Jones, Luca Passamonti, Yong T. Hong, Robert Arnold, et al. 2021. "Relationship between Tau, Neuroinflammation and Atrophy in Alzheimer's Disease: The NIMROD Study." An International Journal on 
medRxiv preprint doi: https://doi.org/10.1101/2022.02.22.22271354; this version posted February 24, 2022. The copyright holder for this preprint (which was not certified by peer review) is the author/funder, who has granted medRxiv a license to display the preprint in It is made available under a CC-BY-NC-ND 4.0 International license .

Information Fusion 67 (March): 116-24.

Swardfager, Walter, Krista Lanctôt, Lana Rothenburg, Amy Wong, Jaclyn Cappell, and

Nathan Herrmann. 2010. “A Meta-Analysis of Cytokines in Alzheimer's Disease.” Biological Psychiatry 68 (10): 930-41.

Veronese, Mattia, Lucia Moro, Marco Arcolin, Ottavia Dipasquale, Gaia Rizzo, Paul Expert, Wasim Khan, et al. 2019. "Covariance Statistics and Network Analysis of Brain PET Imaging Studies.” Scientific Reports 9 (1): 2496.

Vogel, Jacob W., Yasser Iturria-Medina, Olof T. Strandberg, Ruben Smith, Elizabeth Levitis, Alan C. Evans, Oskar Hansson, Alzheimer's Disease Neuroimaging Initiative, and Swedish BioFinder Study. 2020. "Spread of Pathological Tau Proteins through Communicating Neurons in Human Alzheimer's Disease.” Nature Communications 11 (1): 2612.

Vogels, Thomas, Adriana-Natalia Murgoci, and Tomáš Hromádka. 2019. “Intersection of Pathological Tau and Microglia at the Synapse." Acta Neuropathologica Communications 7 (1): 109 .

Völk, Stefanie, Marcus Unterrainer, Nathalie L. Albert, Joachim Havla, Lisa Ann Gerdes, Minh Schumacher, Matthias Brendel, et al. 2020. "TSPO PET With 18F-GE-180 to Differentiate Variants of Multiple Sclerosis: Relapsing-Remitting Multiple Sclerosis, Tumefactive Demyelination, and Baló's Concentric Sclerosis." Clinical Nuclear Medicine 45 (10): e447-48. 
medRxiv preprint doi: https://doi.org/10.1101/2022.02.22.22271354; this version posted February 24, 2022. The copyright holder for this preprint (which was not certified by peer review) is the author/funder, who has granted medRxiv a license to display the preprint in It is made available under a CC-BY-NC-ND 4.0 International license .

\section{Tables}

Table 1: Sociodemographic, clinical and biomarker characteristics of the cohort

\begin{tabular}{|c|c|c|c|}
\hline Characteristic & $\mathbf{C N}$ & AD patients & P-value \\
\hline Age [years] (SD) & $69.22(7.53)$ & $71.31(7.52)$ & 0.35 \\
\hline Sex & $10 / 18(56 \%)$ woman & $18 / 32(56 \%)$ woman & 0.60 \\
\hline Weight [kg] (SD) & $76.39(17.23)$ & $69.50(13.78)$ & 0.13 \\
\hline Education [years] (SD) & $14.83(3.97)$ & $14.81(4.13)$ & 0.99 \\
\hline CDR sob (SD) & $0.06(0.16)$ & $3.16(1.73)$ & $<0.001$ \\
\hline CERAD-NB (SD) & $86.42(5.93)$ & $58.53(14.05)$ & $<0.001$ \\
\hline MMSE (SD) & $29.28(1.07)$ & $24.25(3.17)$ & $<0.001$ \\
\hline CSF Aß42 [pg/ml] (SD) & $1060.41(482.93)$ & $465.96(167.51)$ & $<0.001$ \\
\hline CSF Aß42/40-ratio (SD) & $7.48(1.01)$ & $3.58(0.96)$ & $<0.001$ \\
\hline CSF ptau181 [pg/ml] (SD) & $49.75(17.39)$ & $102.17(46.78)$ & $<0.001$ \\
\hline CSF ttau [pg/ml] (SD) & $230.37(105.57)$ & $635.21(606.34)$ & 0.009 \\
\hline CSF sTREM2 [ng/ml] (SD) & $10.35(3.00)$ & $11.31(3.49)$ & 0.37 \\
\hline TSPO PET SUVR (SD) & $0.94(0.04)$ & $1.08(0.08)$ & $<0.001$ \\
\hline APOE $\varepsilon 4$ allele carriers (SD) & $4 / 18(22 \%)$ & $23 / 29(79 \%)$ & $<0.001$ \\
\hline \multirow[t]{3}{*}{ rs6971 binding status (SD) } & $15 / 18(83 \%) \mathrm{MAB}$ & $6 / 30(20 \%) \mathrm{LAB}$ & 0.041 \\
\hline & $3 / 18(17 \%) \mathrm{HAB}$ & $15 / 30(50 \%) \mathrm{MAB}$ & \\
\hline & & 9/30 (30\%) HAB & \\
\hline
\end{tabular}

Abbreviations: AD, Alzheimer's disease; CN, cognitively normal controls; CDR SoB,

Clinical Dementia Rating Sum of Boxes; CERAD-NB, Consortium to Establish a Registry for Alzheimer's Disease neuropsychological battery total score; MMSE, Mini-Mental Status Examination; $A \beta 42$, amyloid- $\beta$ 42; $A \beta$-Ratio, Ratio $A \beta 42$ to $A \beta 40$; ptau, phosphorylated tau protein; ttau, total tau protein; sTREM2, soluble triggering receptor expressed on myeloid cells 2; TSPO SUVR, mitochondrial translocator protein standardized uptake value; $A P O E$, Apolipoprotein E; LAB, low-affinity binder; MAB, mixed-affinity binder; HAB, high-affinity binder. 
medRxiv preprint doi: https://doi.org/10.1101/2022.02.22.22271354; this version posted February 24, 2022. The copyright holder for this preprint (which was not certified by peer review) is the author/funder, who has granted medRxiv a license to display the preprint in It is made available under a CC-BY-NC-ND 4.0 International license

Table 2: Regions with highest TSPO PET tracer uptake in Alzheimer's disease compared with cognitively normal controls

\section{Left hemisphere}

$$
\text { Parahippocampal Uncus }
$$$$
\text { (Amygdala) }
$$

Centroid (MNI Coordinates)

Voxels

Threshold (P-Value)

Voxel Threshold

$$
\mathrm{x}=-22, \mathrm{y}=-8, \mathrm{z}=-20
$$

34

0.001

\section{Right hemisphere}

Parahippocampal Uncus

(Amygdala)

$$
\mathrm{x}=22, \mathrm{y}=-2, \mathrm{z}=-20
$$

0.001 
medRxiv preprint doi: https://doi.org/10.1101/2022.02.22.22271354; this version posted February 24 , 2022. The copyright holder for this preprint (which was not certified by peer review) is the author/funder, who has granted medRxiv a license to display the preprint in It is made available under a CC-BY-NC-ND 4.0 International license .

\section{Figures}

Figure 1: Flow chart showing the number and reasons for study exclusions.

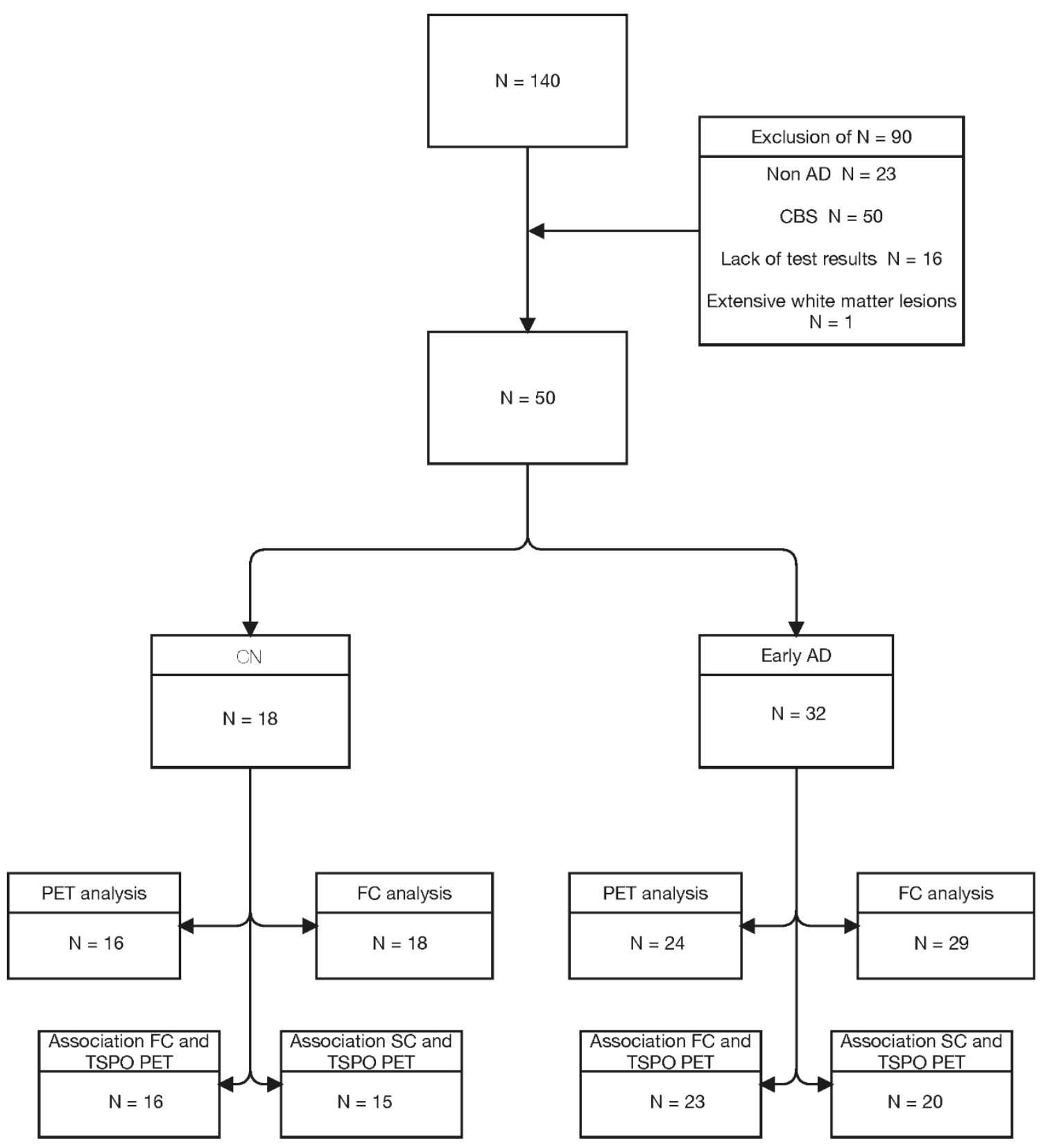

Abbreviations: AD, Alzheimer's disease; CN, cognitively normal; CBS, Corticobasal syndrome; FC, functional connectivity; SC, structural connectivity; TSPO, mitochondrial translocator protein. 
medRxiv preprint doi: https://doi.org/10.1101/2022.02.22.22271354; this version posted February 24, 2022. The copyright holder for this preprint (which was not certified by peer review) is the author/funder, who has granted medRxiv a license to display the preprint in It is made available under a CC-BY-NC-ND 4.0 International license

Figure 2: (A) Voxel wise group comparisons between Alzheimer's disease and cognitively normal controls $(\mathrm{p}<0.001)$; scatterplot showing individual and mean differences between patients and cognitively normal controls in mitochondrial translocator protein standardized uptake value (SUVR). (B) Group differences in region of interest-based functional connectivity between Alzheimer's disease and cognitively normal controls on whole brain level (cognitively normal controls $<$ patients, FDR corrected $\mathrm{p}<0.05$ ). (C) Differences in structural connectivity using diffusion tensor imaging-derived numbers of tracts on whole brain level (cognitively normal controls $<$ patients, FDR corrected $\mathrm{p}<0.05$ ). The numbers in the connectome ring in B) and C) correspond to regions in the Brainnetome atlas (Supplementary Table 1). 
medRxiv preprint doi: $h$ ttps://doi.org/10.1101/2022.02.22.22271354; this version posted February 24, 2022. The copyright holder for this preprint (which was not certified by peer review) is the author/funder, who has granted medRxiv a license to display the preprint in It is made available under a CC-BY-NC-ND 4.0 International license.

\section{A}
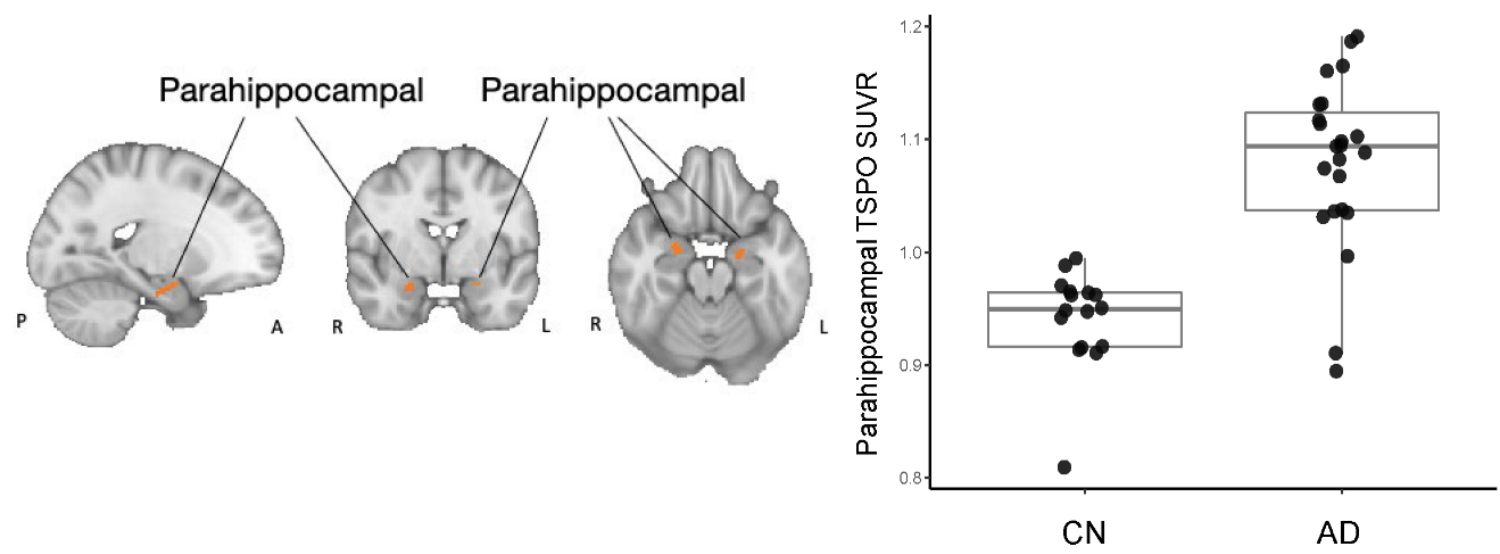

B

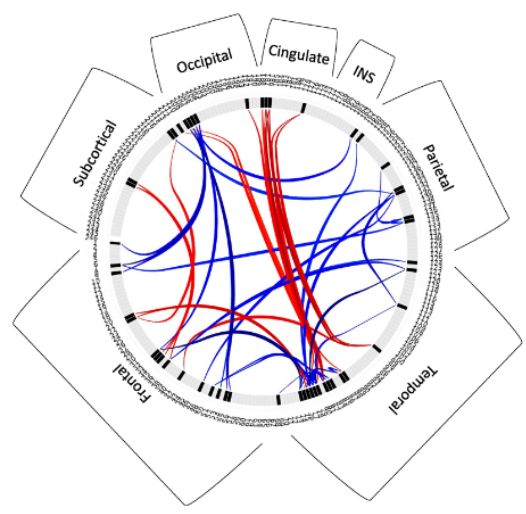

L

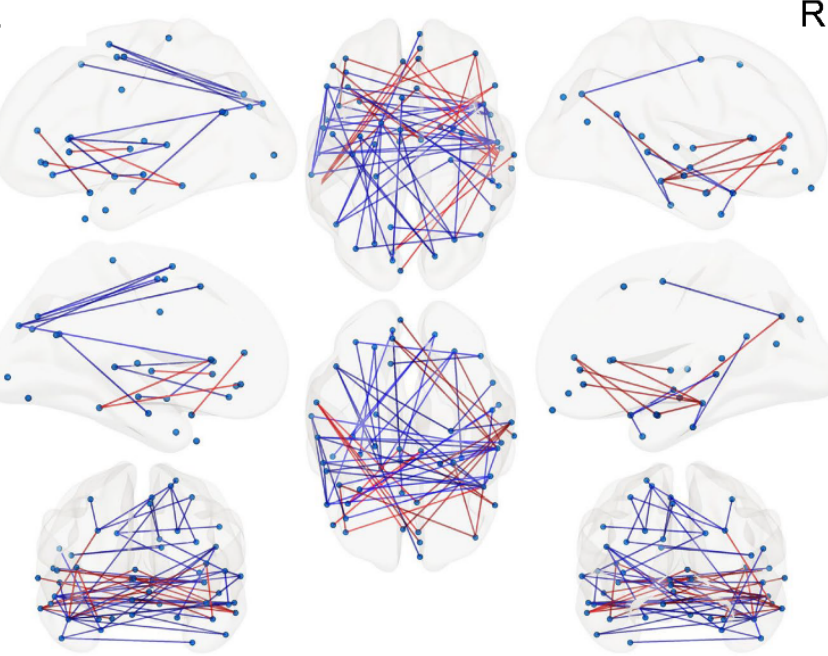

C
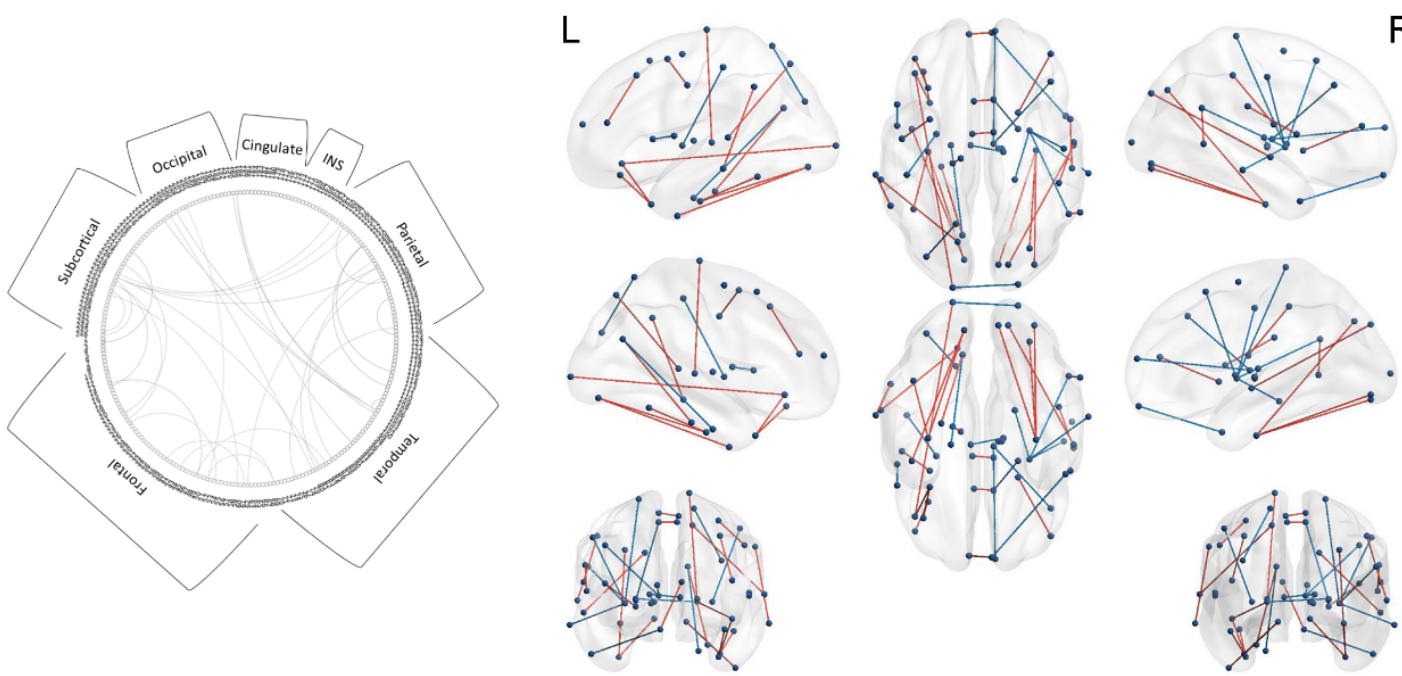

Abbreviations: AD, Alzheimer's disease; CN, cognitively normal controls; TSPO,

mitochondrial translocator protein; SUVR, standardized uptake value; L left; R, right. 
medRxiv preprint doi: https://doi.org/10.1101/2022.02.22.22271354; this version posted February 24, 2022. The copyright holder for this preprint (which was not certified by peer review) is the author/funder, who has granted medRxiv a license to display the preprint in It is made available under a CC-BY-NC-ND 4.0 International license

Figure 3: Associations between dementia severity and cognitive impairment and parahippocampal TSPO PET uptake in the whole study cohort, adjusted for age, sex, TSPO binding status and diagnostic group.
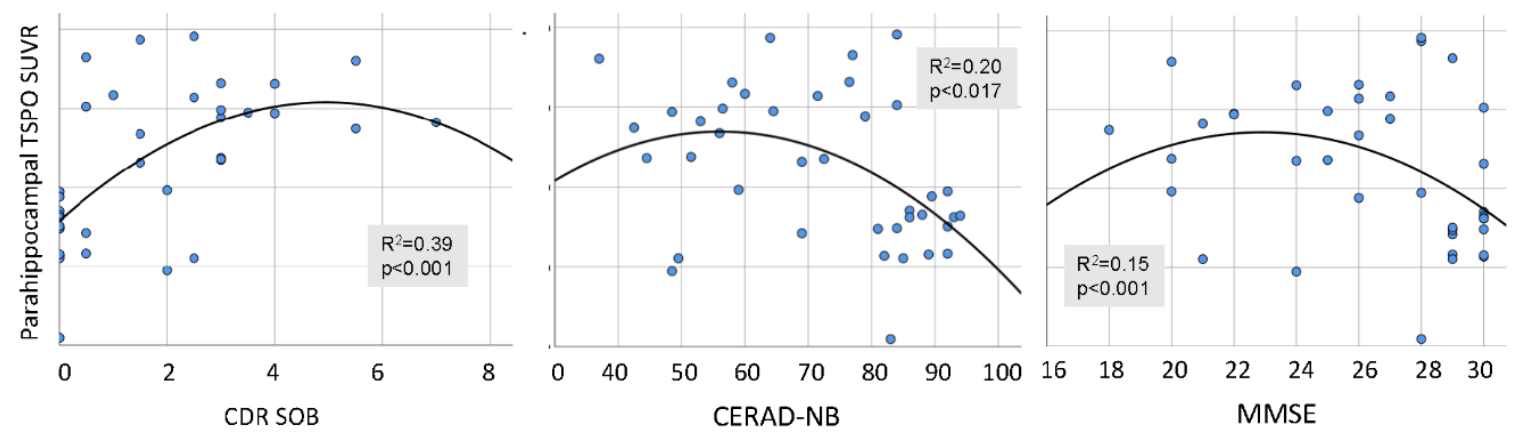

Abbreviations: TSPO SUVR, mitochondrial translocator protein standardized uptake value;

CDR SOB, Clinical Dementia Rating Sum of Boxes; CERAD-NB, Consortium to Establish a Registry for Alzheimer's Disease neuropsychological battery total score; MMSE, MiniMental Status Examination. 
medRxiv preprint doi: $h$ ttps://doi.org/10.1101/2022.02.22.22271354; this version posted February 24, 2022. The copyright holder for this preprint (which was not certified by peer review) is the author/funder, who has granted medRxiv a license to display the preprint in It is made available under a CC-BY-NC-ND 4.0 International license .

Figure 4: (A) Mean TSPO PET covariance matrix of cognitively normal controls and Alzheimer's disease patients. (B) Mean adjacency matrix of functional connectivity (C) Mean adjacency matrix of structural connectivity.

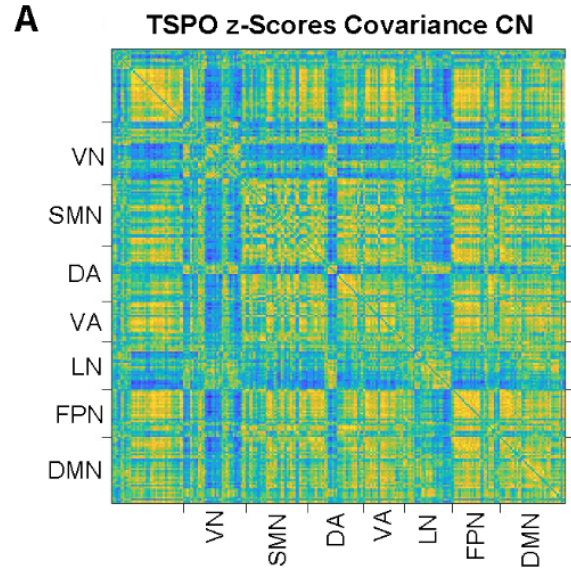

$\mathbf{B}$

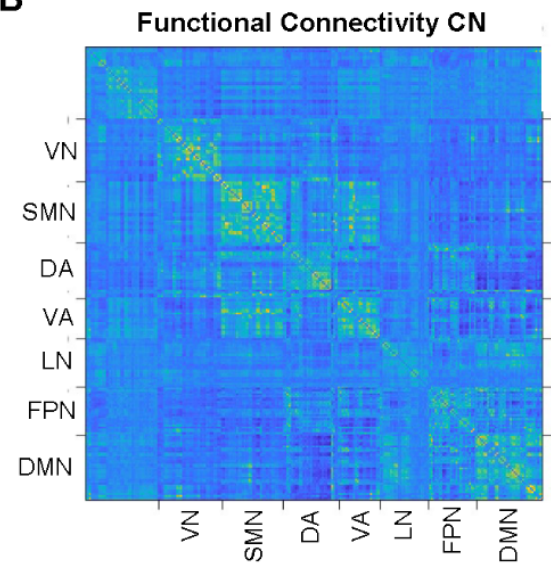

C

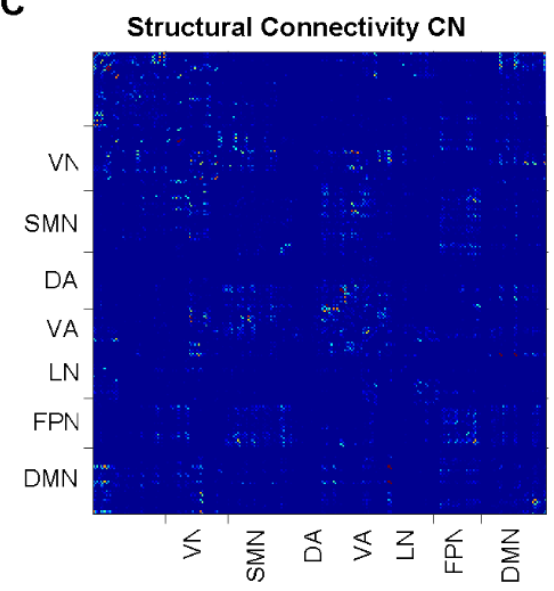

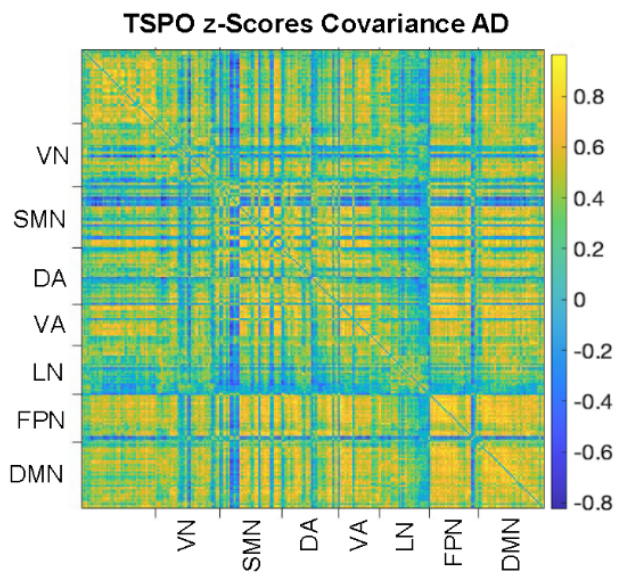
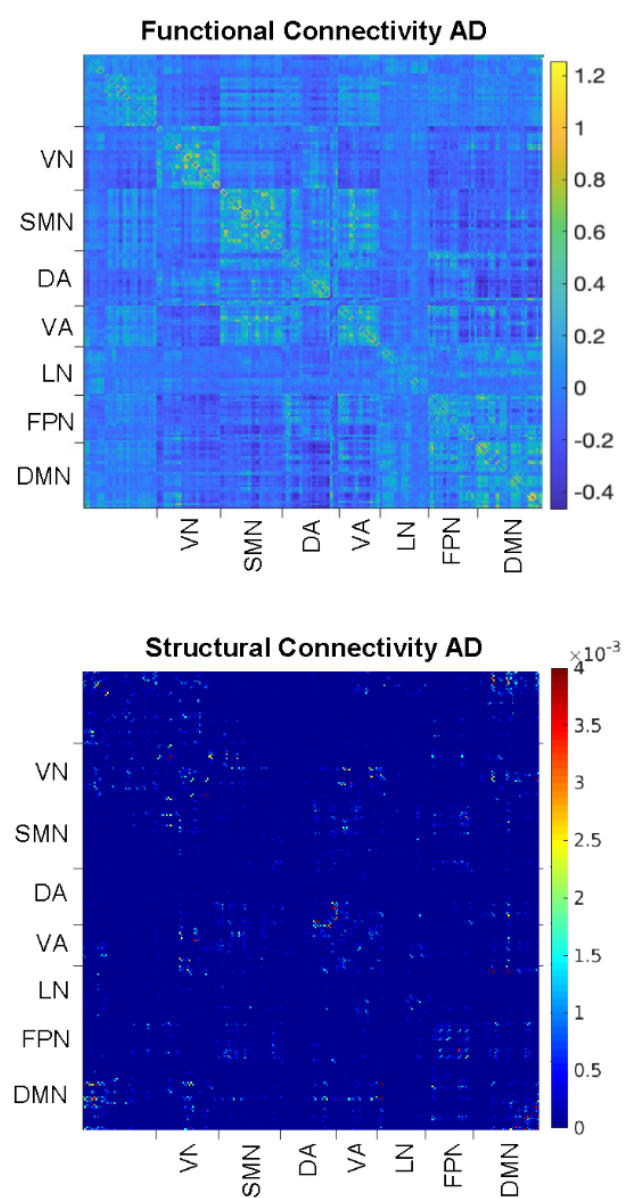

Abbreviations: AD, Alzheimer's disease; CN, cognitively normal controls; TSPO, mitochondrial translocator protein; SUVR, standardized uptake value; L left; R, right; VN, visual network, SMN, sensorimotor network, DA, dorsal attention network; VA, ventral 
medRxiv preprint doi: https://doi.org/10.1101/2022.02.22.22271354; this version posted February 24, 2022. The copyright holder for this preprint (which was not certified by peer review) is the author/funder, who has granted medRxiv a license to display the preprint in It is made available under a CC-BY-NC-ND 4.0 International license.

attention network; LN, limbic network; FPN, fronto parietal network; DMN, default mode network.

Figure 5: (A) Associations between functional connectivity and TSPO PET microglial activation. (B) Associations between structural connectivity and TSPO PET microglial activation.

A

CN

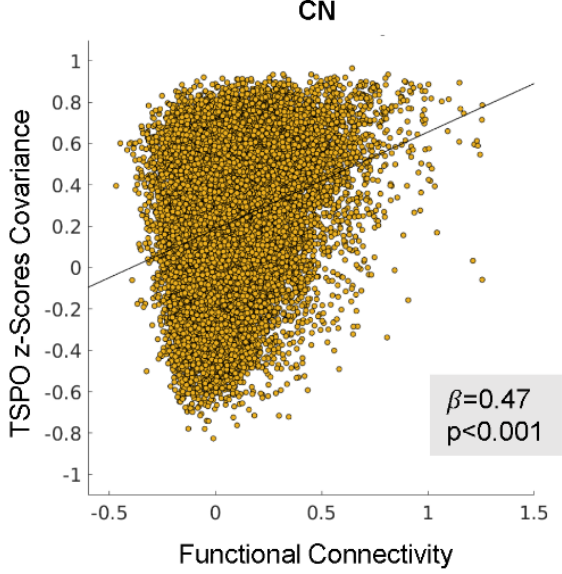

B

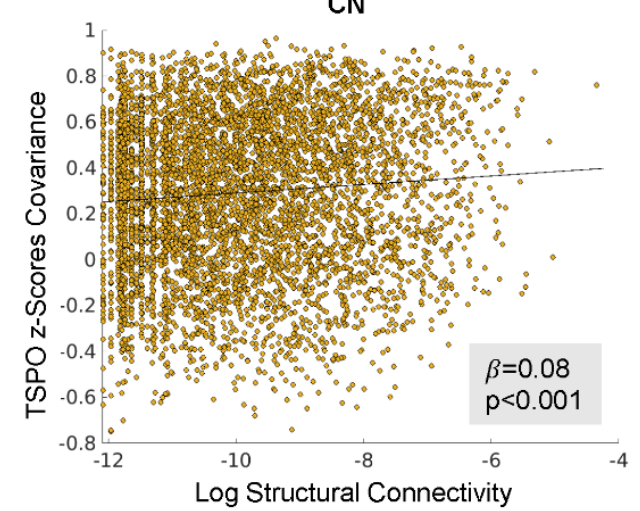

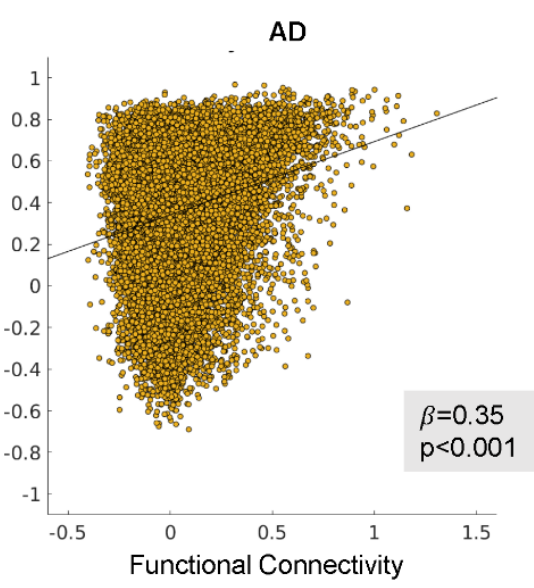

AD

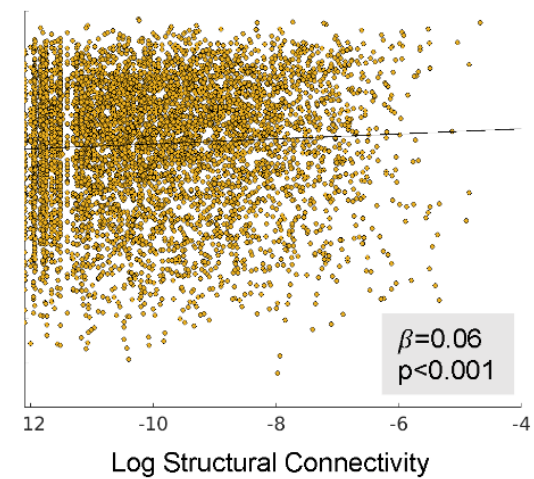

Abbreviations: AD, Alzheimer's disease; CN, cognitively normal controls; TSPO, mitochondrial translocator protein; Log, logarithm. 
medRxiv preprint doi: https://doi.org/10.1101/2022.02.22.22271354; this version posted February 24, 2022. The copyright holder for this preprint (which was not certified by peer review) is the author/funder, who has granted medRxiv a license to display the preprint in It is made available under a CC-BY-NC-ND 4.0 International license.

\section{Figure 6:}

Connectivity is associated with TSPO PET uptake in the target regions depending on TSPO

PET uptake in a seed region. (A) shows the associators for functional connectivity and (B) for structural connectivity.

A

CN

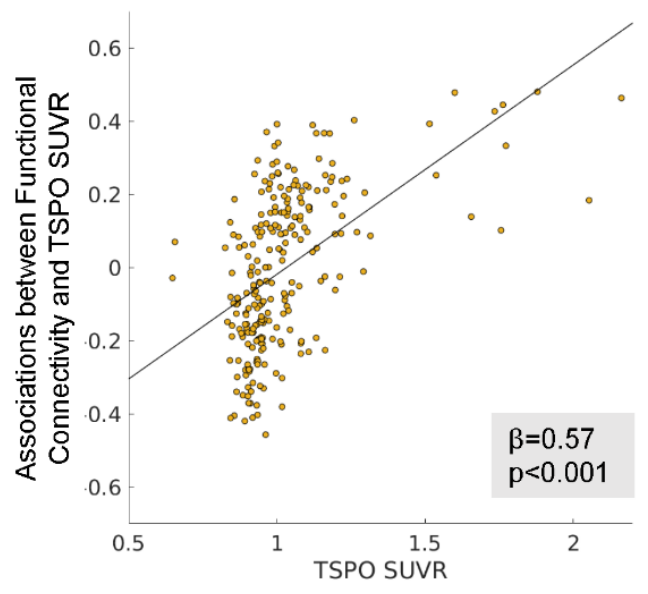

$\mathbf{B}$

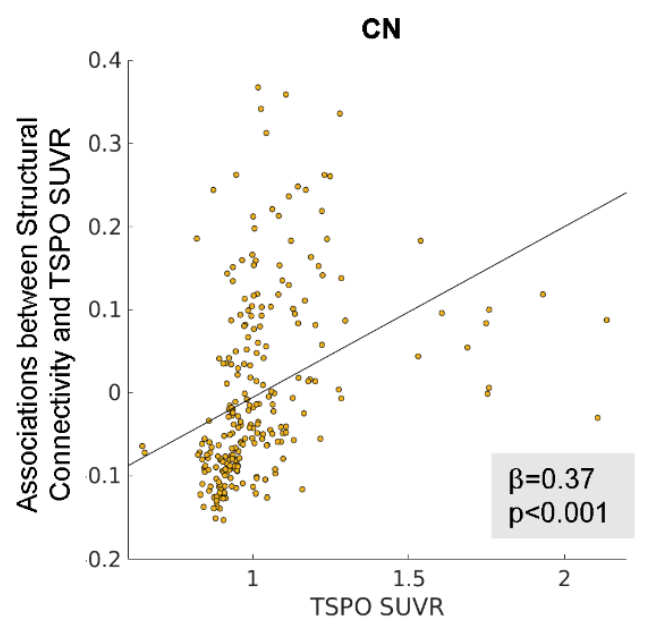

AD

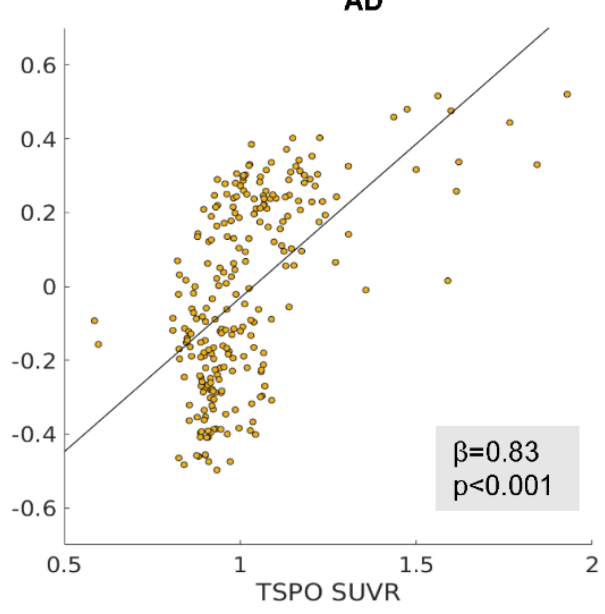

AD

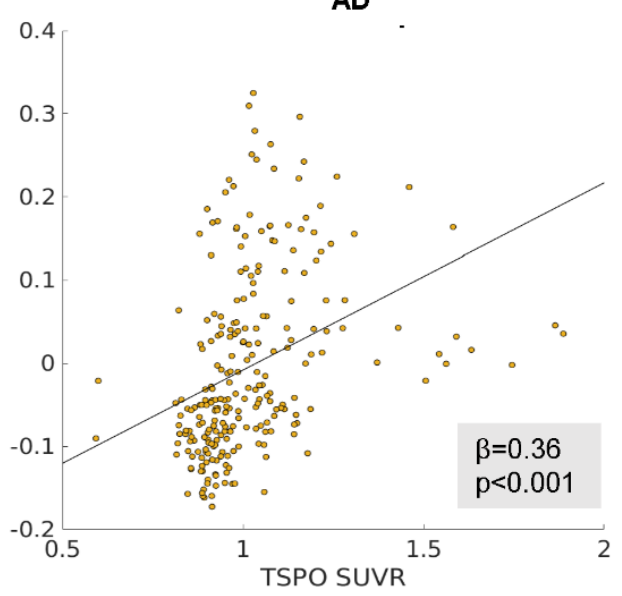

Abbreviations: AD, Alzheimer's Disease; CN, cognitively normal controls; TSPO SUVR, mitochondrial translocator protein standardized uptake value. 
medRxiv preprint doi: https://doi.org/10.1101/2022.02.22.22271354; this version posted February 24, 2022. The copyright holder for this preprint (which was not certified by peer review) is the author/funder, who has granted medRxiv a license to display the preprint in It is made available under a CC-BY-NC-ND 4.0 International license.

Figure 7: Associations between TSPO PET tracer uptake and (A) functional connectivity in TSPO PET hot spot in temporo-occipital (Brainnetome region 190) and TSPO PET cold spot in the caudate nucleus/basal ganglia (Brainnetome regions 227/228). (B) structural connectivity in TSPO PET hot spot in temporo-occipital (Brainnetome region 190) and TSPO PET cold spot in the caudate nucleus/basal ganglia (Brainnetome region 227/228).
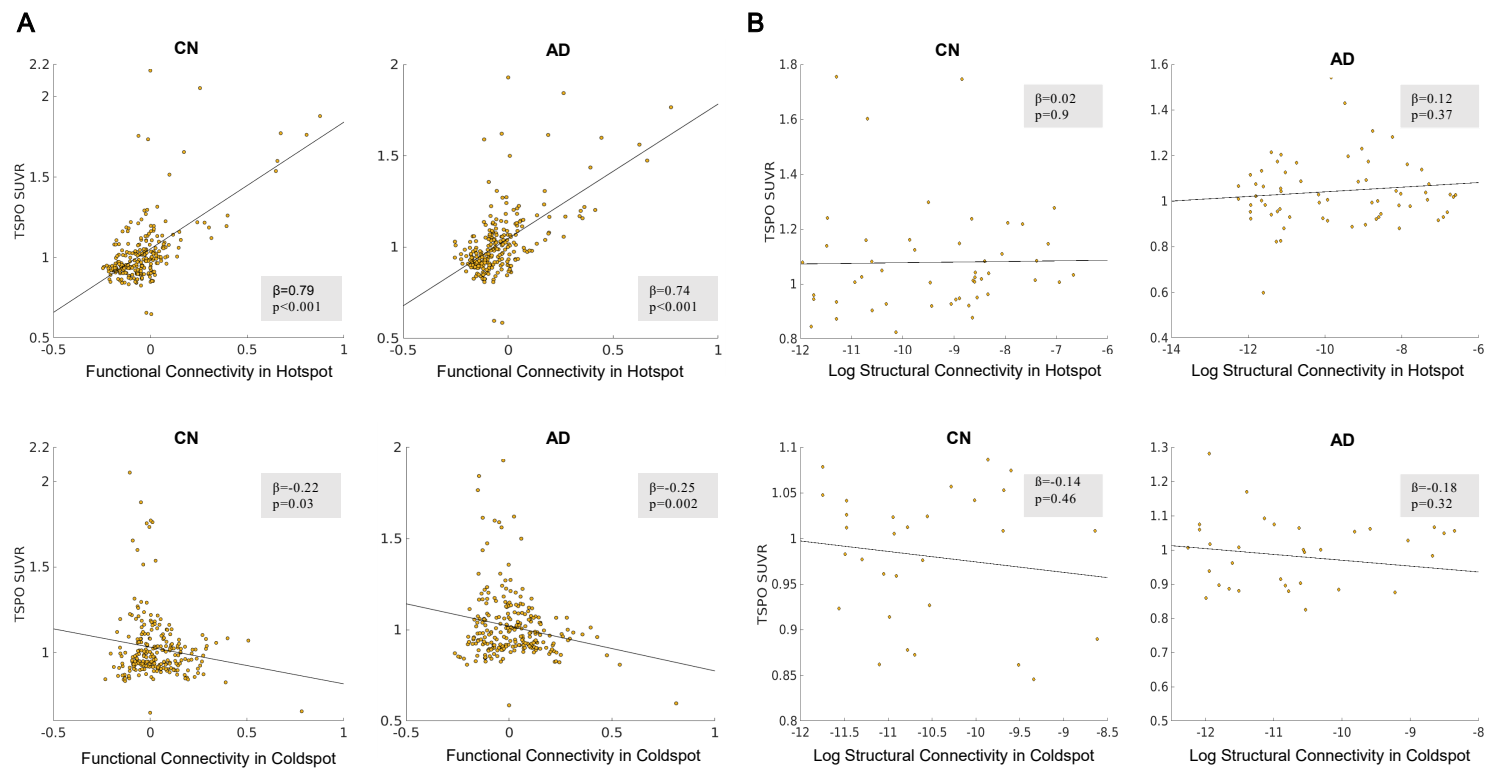

Abbreviations: AD, Alzheimer's Disease; CN, cognitively normal controls; TSPO SUVR, mitochondrial translocator protein standardized uptake value; Log, logarithm. 